\title{
Psychologiczne decyzje podejmowania pracy poniżej swoich kwalifikacji w kontekście wartości
}

\author{
Ewelina Okoniewska \\ https://orcid.org/0000-0003-2695-5457
}

Celem przeprowadzonych badań była odpowiedź na pytanie, jakie wartości wpływają na sytuację osoby podejmującej decyzję o podjęciu rekrutacji w grupie osób aplikujących na dane stanowisko poniżej swoich kwalifikacji. W związku z tak postawionym pytaniem przebadano 302 kandydatów w 11 miastach w Polsce (Lublin, Warszawa, Rzeszów, Lipsko, Poznań, Kielce, Sandomierz, Gorzyce, Opole, Łódź, Krosno). Osoby badane były w wieku od 18 do 45 lat. Badane były osoby, które uczestniczyły w procesie rekrutacji. Wypełniły one kwestionariusz, który w pierwszej części zawierał metryczkę, doświadczenie zawodowe z trzech ostatnich miejsc pracy. W dalszej części znajdował się Kwestionariusz Wartości Schwartza PVQ- R2. Artykuł jest pomocnym źródłem wiedzy na temat opisu profilu kandydata aplikującego poniżej swoich kwalifikacji pod kątem jego wartości. Badania mogą być pomocne dla osób zajmujących się rekrutacją i selekcją personelu lub rozwojem zasobów ludzkich.

Słowa kluczowe: wartości, decyzje, praca poniżej kwalifikacji, wartości Schwartza

\section{Decyzje w psychologii}

Obecnie możemy wyróżnić dwa rodzaje zastosowań teorii decyzji w nauce. Z jednej strony wykorzystuje się ją do kształtowania polityki naukowej, takiej jak planowanie tematyki naukowej, dobór kadr i dystrybucji środków finansowych,

EWELINA OKONIEWSKA, doktor, Uniwersytet Jana Kochanowskiego w Kielcach; adres do korespondencji: 25-029 Kielce, ul. Krakowska 11; e-mail: ewelina.okoniewska@ujk.edu.pl 
a także w celu opracowania racjonalnej organizacji instytutów badawczych oraz zarządzaniu nimi. $Z$ drugiej strony możemy ją wykorzystać do rozwiązywania pojedynczych problemów badawczych podejmowanych przez różnych naukowców, którzy stawiają określone hipotezy i starają się je zweryfikować1.

Decyzja, jak sama nazwa wskazuje (od łacińskiego decidere - ujęcie, przecięcie), to moment przecięcia. Owe przecięcie odnosi się do teraźniejszości oraz do zmiany konsekwencji poprzednich decyzji, ponieważ wiąże się z kształtowaniem bytu podmiotowo-osobowego ${ }^{2}$. Rozpatrując pojęcie decyzji na płaszczyźnie biologicznej, można rozumieć jako serię przypadkowych zdarzeń, które prowadzą do konieczności pojęcia działania. Ujęcie to oznacza redukcjonistyczne traktowanie decyzji jako impulsu i ogranicza możliwość interpretacji tego zjawiska³.

Psychologowie zajmujący się badaniem czynności decyzyjnych interesują się cechami decydenta jako układu dokonującego wyboru. W obrębie zainteresowań znajduje się analiza zachowań decydenta, zachodzące u niego procesy poznawcze oraz jego osobowość. Decydentem jest jednostka, osoba, która dokonuje wyboru i ponosi odpowiedzialność za swoją decyzję̧ . Bardzo ważną cechą jest odpowiedzialność, która jest związana z ponoszeniem konsekwencji dokonywanych wyborów. W związku z tym, osoba dokonująca wyboru akceptuje alternatywę, utożsamia się również z celami jej wyboru.

Decydent posiada cechy istotne dla procesu podejmowania decyzji. Pierwsza grupa to cechy niezmienne, które są najbardziej ogólnymi właściwościami układów $^{5}$. Cechy te posiadają wszyscy decydenci; odgrywają inne role w rozwiązywaniu decyzji wszystkich typów. Przykładem takiej cechy jest ukierunkowanie na realizację określonych celów. U decydenta występuje tylko ograniczona liczba cech niezmiennych, które ujawniają się podczas wyboru, a oprócz ukierunkowania na cele należy do nich charakterystyka układów pamięci oraz uporządkowana struktura czynności poznawczych. Formą zachowania celowego, planowane przez daną osobę jest uczestnictwo w rekrutacji ${ }^{6}$. W tym ujęciu nie jest to jednorazowy akt,

\footnotetext{
${ }^{1}$ Józef Kozielecki, Psychologiczna teoria decyzji (Warszawa: PWN, 1975).

${ }^{2}$ Mieczysław Krąpiec, „Decyzja - bytem moralnym”, Roczniki Filozoficzne 31, nr 2 (1983): 31; tenże, Ludzka wolność i jej granice (Lublin: Polskie Towarzystwo Tomasza z Akwinu, 2004).

${ }^{3}$ John Adair, Podejmowanie decyzji (Warszawa: Studio emKa, 1998).

${ }^{4}$ Adam Biela, Informacja a decyzja (Warszawa: PWN, 1976).

${ }^{5}$ Kozielecki, Psychologiczna teoria decyzji.

${ }^{6}$ Peter Gollwitzer, „Implementation intentions: Strong effects of simple plans”, American Psychologist 54, nr 7 (1999): 493-503, DOI: 10.1037/0003-066X.54.7.493.
} 
lecz proces, którego finalną fazą jest podjęcie i ukończenie działania, tj. uzyskanie pracy.

Podejmowanie decyzji to złożony proces psychiczny, w którym uczestniczą elementy poznawcze, emocjonalne i motywacyjne. Na to, jaką decyzję człowiek podejmie, wpływa jego wiedza i doświadczenie ${ }^{7}$, a także świadomość decydenta oraz związki grupowe ${ }^{8}$. Decydent $w$ trakcie podejmowania decyzji znajduje się w określanych fazach. Przed podjęciem decyzji w fazie przeddecyzyjnej decydent definiuje problem decyzyjny i zbiera informacje na temat dostępnych rozwiązań. W zależności od tego, jak bardzo złożony jest problem, decydent będzie gromadził potrzebne informacje ${ }^{9}$. Często w tej fazie człowiek pragnie dojść do swojego celu, ale nie wie jeszcze, w jaki sposób może go rozwiązać ${ }^{10}$. Człowiek, który jest w takiej sytuacji problemowej, może nie podejmować żadnych działań lub próbować osiągnąć cel mimo braku dostępnych środków, tak jak może uczestniczyć w procesie rekrutacji mimo braku tożsamych wartości.

\section{Wartości}

Pojęcie wartości posiada wiele znaczeń i występuje w wielu dziedzinach naukowych, jak psychologia, socjologia, filozofia, antropologia i teologia. Cytując filozofa Nicolai Hartmanna, możemy sformułować kilka zasadniczych tez odnośnie do „aksjologicznie” rozumianych wartości: „1. nasze życie jest pełne treści pozytywnie wartościowych [...]; 2. ta wartościowa zawartość jest wszędzie pomieszana z treściami negatywnie wartościowymi; 3 . wartościowe byty w świecie wymagają od nas, byśmy wobec nich zajmowali właściwą postawę [...]; 4. wartości wymagają,

${ }^{7}$ Ola Svenson, „Differentiation and consolidation theory of human decision making: A frame of reference for the study of pre- and postdecision process", Acta Psychologica 80, nr 1-3 (1992): 143-172, DOI: 10.1016/0001-6918(92)90044-E.

${ }^{8}$ Emma Bäck i in., „Post decision consolidation in large group decision making”, Scandinavian Journal of Psychology 52, nr 4 (2011): 320-328.

${ }^{9}$ Andrzej Falkowski, Tadeusz Tyszka, Psychologia zachowań konsumenckich (Gdańsk: Gdańskie Wydawnictwo Psychologiczne, 2001); Tadeusz Tyszka, Decyzje. Perspektywa psychologiczna ekonomiczna (Warszawa: Wydawnictwo Naukowe Scholar, 2010).

${ }^{10}$ Allen Newell, Herbert Simon, Human problem solving (Englewood Cliffs: Prentice Hall, 1972). 
abyśmy je realizowali"11. Interesujące ujęcie wartości przedstawił Max Scheler ${ }^{12}$. Według niego, wartości występuję według pewnej hierarchii. Najwyżej znajdują się wartości religijne, zwane sakralnymi, następnie niżej wartości duchowe (kulturowe) na które składają się: estetyczne (piękno), prawne (porządek, sprawiedliwość), poznawcze (prawda). Poniżej występują także wartości witalne, hedonistyczne (przyjemnościowe) oraz utylitarne, użytecznościowe. Wartości te stanowią wiecznotrwałą hierarchię, z wartościami religijnymi jako najwyższymi w stosunku do pozostałych. Każda wartość wyższa nadaje sens niższej (pieniądz jest absurdalny, jeśli nie służy przyjemności; przyjemność, jeśli nie wzmacnia naszych sił witalnych, życie ma sens dzięki temu, że poświęca się je jakiejś idei).

W psychologii termin „wartości” często jest używany zamiennie z takimi pojęciami. jak „postawy”, „cele życiowe”, „ambicje”, „potrzeby”, „dążenia”. Milton Rokeach wyróżnił wartości instrumentalne, które są związane z określonymi sposobami zachowania, oraz wartości ostateczne, związane $\mathrm{z}$ własnymi przekonaniami ${ }^{13}$. W pierwszej grupie znajdują się wartości moralne i kompetencyjne (twórcza wyobraźnia, ambicja), a w drugiej wartości społeczne i indywidualne (harmonia wewnętrzna). Badacz ten umiejscowił wartości w centralnym punkcie struktury osobowości. Twierdził, że ich komponenty poznawcze, emocjonalne i behawioralne są podobne do tych w postawach, jednakże są od postaw ważniejsze. Są bardziej dynamiczne, warunkują postawy i zachowania, pełnią wobec nich rolę nadrzędną. Jeśli zmienia się u jednostki hierarchia wartości, to jednocześnie zmienia się u niej cały system poznawczy. G. W. Allport wskazywał, że wartości stanowią podstawę rozwoju osobowości. Według niego, są one wzorcami warunkującymi stawianie sobie przez jednostkę celów oraz wybór określonych form zachowania. Wiążą się przez to $\mathrm{z}$ budowaniem idealnego obrazu siebie, ze spostrzeganiem rzeczywistości wewnętrznej i zewnętrznej, z procesem myślenia, podejmowania decyzji, czy kształtowania nawyków ${ }^{14}$.

${ }^{11}$ Nicolai Hartmann, „O idealnej samoświadomości wartości. Stosunek wartości i powinności. Aktualny stan zagadnienia wartości”, w: $Z$ fenomenologii wartości, red. Włodzimierz Galewicz (Kraków: Wydawnictwo PAT, 1988).

${ }^{12}$ Max Scheler, Cierpienie, śmierć i dalsze życie, tłum. Adam Wegrzecki (Warszawa: PWN, 1994).

${ }^{13}$ Anna Tomkiewicz, Ewa Popławska, „Postawy wartościujące studentów polskich i amerykańskich”, Roczniki Nauk Społecznych XXV, z. 2 (1997): 45-66.

${ }^{14}$ Piotr Oleś, Wartościowanie a osobowość. Psychologiczne badanie empiryczne (Lublin: Wydawnictwo KUL, 1989). 
Bardzo dojrzałą i uniwersalną koncepcję wartości przedstawił Shalom Schwartz, posługując się kontinuum treściowym utworzonym w postaci koła. Schwarz, podobnie jak Rokeach, definiuje wartości jako postawy, które w trakcie aktywizowania wywołują pozytywne lub negatywne emocje. Schwartz ${ }^{15}$ podkreśla, że funkcjonowanie wartości jako stanów nie jest do końca świadome, a uświadomienie najczęściej następuje w sytuacjach konfliktów kilku wartości. Odrzuca wartości instrumentalne, a za właściwe rozumienie uznaje wyłącznie wartości ostateczne. Definiuje je jako przekonania dotyczące ostatecznych stanów egzystencji, celów ludzkiego życia. Autor ten przedstawia skończony katalog wartości na kontinuum kołowym, dokonuje pogrupowania wartości i wykazuje ich wzajemną relacyjność kierując się regułą zgodności i regułą konfliktu motywacyjnego ${ }^{16}$. W teorii Schwartza zwraca się uwagę na dwie charakterystyki struktury wartości. Pierwsza z nich sugeruje, że wartości tworzą kontinuum motywacyjne, co oznacza, że wartości podobne, usytuowane obok siebie, mogą być realizowane w jednym akcie działania. W drugiej charakterystyce zwraca się uwagę na kołowość struktury. Wartości podobne znajdują się blisko siebie, a wartości przeciwległe w modelu kołowym nie mogą być realizowane w jednym akcie działania. $\mathrm{Na}$ postawie teorii Schwartza powstał Portretowy Kwestionariusz Wartości Schwartza. Najnowsza przyjęta i zmodyfikowana wersja Kwestionariusza PVQR2, która została opracowana przez Jana Cieniucha i Zbigniewa Zaleskiego, składa się z 19 wartości. Metoda ta została zastosowana w tychże badaniach.

\section{Przegląd badań}

Przez ostatnie 20 lat w publikacjach polskich i zagranicznych z dziedziny psychologii organizacji, socjologii czy ekonomii, które dotyczą pracy, przeważnie poruszano temat bezrobocia i jego konsekwencji ${ }^{17}$. Badaczy interesują przyczyny po-

${ }^{15}$ Shalom Schwartz, „Robustness and fruitfulness of a theory of universals in individual human values”, Valores e trabalho (2005): 56-85. Tenże, „Basic human values: theory measurement and applications", Revue francaise de sociologie 47, nr 4 (2006): 929-968, DOI: 10.1037/0003-066X.54.7.493

${ }^{16}$ Jan Cieciuch, „Pomiar wartości w zmodyfikowanym modelu Shaloma Schwartza”, Psychologia Społeczna 8, nr 1 (2013): 22-41.

${ }^{17}$ Jan Terelak, Psychologia pracy i bezrobocia (Warszawa: Wydawnictwa Akademii Teologii Katolickiej, 1993), 268; Mieczysław Kabaj, Badanie bezrobocia długotrwałego (Warszawa: IPiSS, 2001); Robert Flynn, „Effect of unemployment on depressive affect,” w: Depression and the social environment: 
wstawania bezrobocia, jego poziom obecny oraz opracowania gospodarcze związane $\mathrm{z}$ działaniami prewencyjnymi. Obecne zainteresowanie problematyką niedostatecznego zatrudnienia ma związek przede wszystkim z przemianami na współczesnym rynku pracy. Zdaniem wielu badaczy, globalizacja ekonomiczna i rozwój technologiczny, który umożliwia umiejscowienie zakładów produkcyjnych w krajach oferujących tak zwaną „tanią siłę roboczą”, są źródłem silnej presji wśród wielu krajów w kierunku obniżania kosztów pracy ${ }^{18}$. Efektem takiego stanu rzeczy jest coraz większa popularność alternatywnych, tak zwanych elastycznych form zatrudnienia. Takie formy zatrudnienia są oparte na warunkach odmiennych od tych, które obowiązują w tradycyjnym modelu pracy na pełnym etacie.

W kontekście psychologii organizacji ważne jest, że wartości wpływają na kulturę organizacyjną firmy, a co za tym idzie - na jej pracowników. Wspólne wartości wynikające z obowiązującej kultury organizacyjnej tworzą siły motywacyjne, a wcześniej stanowią wskazówki przy formułowaniu celów i misji przedsiębiorstwa ${ }^{19}$. Dzięki temu możliwe jest utrzymanie motywacji (automotywacji) pracowników na wysokim poziomie przy jednoczesnym rozwoju całej organizacji i jej uczestników. Działanie takie wymaga wskazania obowiązujących w organizacji reguł, wartości, przekonań. Zarządzanie przez wartości zakłada więc niwelowanie luki w wartościach postrzeganych i preferowanych, zarówno w kontekście przedmiotowym (organizacji), jak i podmiotowym (pracowników). Oznacza to łączenie osobistych celów $\mathrm{z}$ wartościami przestrzeganymi w firmie ${ }^{20}$. Badania nad system wartości organizacyjnej pozwalają ocenić, jak funkcjonuje dana firmy oraz jej pracownicy ${ }^{21}$.

Research and intervention with neglected populations, red. Philippe Cappeliez, Robert J. Flynn (Montreal: McGill-Queen's University Press, 1993); Stanislav Kasl, Eunice Rodriguez, Kathryn Lasch, „The impact of unemployment on health and well-being", w: Adversity, Stress, and Psychopathology, red. Bruce Dohrenwend (New York: Oxford University Press, 1998): 111-131.

${ }^{18}$ Robert Reich, Praca Narodów. Przygotowanie się do kapitalizmu XXI wieku, tłum. Lidia Zyblikiewicz (Toruń: Wydawnictwo Adam Marszałek, 1996); Lester Thurow, Przyszłość kapitalizmu. Jak dzisiejsze siły ekonomiczne kształtują świat jutra, tłum. Lech Czyżewski (Wrocław: Wydawnictwo Dolnośląskie, 1999).

${ }^{19}$ Agata Stachowicz-Stanusch, Zarządzanie poprzez wartości. Perspektywa rozwoju współczesnego przedsiębiorstwa (Gliwice: Wydawnictwo Politechniki Śląskiej, 2007).

${ }^{20}$ Barbara Fryzeł, Kultura a konkurencyjność przedsiębiorstwa (Toruń: TNOiK Dom Organizatora, 2004).

${ }^{21}$ Cathy Enz, ,The role of value congruity in intraorganizational Power”, Administrative Science Quarterly33, nr 2 (1988): 284-304, DOI: 10.2307/2393060. 
Wartości mogą sprzyjać realizacji potrzeb niższego wyższego rzędu oraz skłaniać do niezgodnych z nimi zachowań; jednostka może mieć wysoką, silną potrzebę bezpieczeństwa, ale ze względu na pewne wartości (z racji wychowania lub światopoglądu) podejmuje działania powodujące zagrożenie. System wartości powiązany jest $\mathrm{z}$ poczuciem własnej wartości ${ }^{22}$, a postępowanie z jego normą skutkuje zadowoleniem lub dumą. System wartości jest motywatorem i regulatorem podejmowanych działań.

\section{Metoda}

Celem przeprowadzonych badań było uzyskanie odpowiedzi na pytanie, jakie są zależności między wartościami życiowymi Schwartza a decyzją o udziale w rekrutacji na stanowisko wymagające niższych kwalifikacji niż posiadane. Pytanie to ma charakter eksploracyjny, dlatego ograniczono się wyłącznie do sformułowania problemu badawczego, bez wyszczególniania hipotez.

W związku z tak postawionym pytaniem przebadano 302 kandydatów w 11 miastach w Polsce (Lublin, Warszawa, Rzeszów, Lipsko, Poznań, Kielce, Sandomierz, Gorzyce, Opole, Łódź, Krosno). Badane osoby były w wieku od 18 do 45 lat. Badani wypełniali kwestionariusz, który w pierwszej części zawierał metryczkę, gdzie kandydaci byli pytani o status zawodowy, płeć, wiek, miejsce zamieszkania, wykształcenie, tryb nauki, status zawodowy, wykonywany zawód, sytuację materialną, uczestnictwo w szkoleniach zwiększających kwalifikacje oraz staż pracy zawodowej. Następnie opisywali swoje doświadczenie zawodowe z trzech ostatnich miejsc pracy. Respondenci określali poziom stanowiska pracy (podstawowe, specjalistyczne, kierownicze), wpisywali zakres obowiązków na danym stanowisku oraz staż pracy podany w miesiącach. Ta część kwestionariusza pozwoliła na określenie u 302 kandydatów na skali od 0 do 9 adekwatności poziomu kwalifikacji do stanowiska, na jakie się ubiegali. W dalszej części ankiety znajdował się Kwestionariusz Wartości Schwartza PVQ-R2.

W badaniach ujęta została zmienna objaśniana zależna, którą jest decyzja o udziale w rekrutacji. Zmienna ta została zoperacjonalizowana na skali rangowej w podziale dychotomicznym na dwie grupy (zakresy). Zmienna decyzja o apliko-

${ }^{22}$ Shalom Schwartz, „Aktywizacja osobistych standardów normatywnych a zachowanie prospołeczne”, Studia Psychologiczne 15 (1976): 5-33. 
waniu poniżej kwalifikacji jest sumą wykształcenia, stażu pracy oraz doświadczenia, które zostało ocenione w ankiecie badawczej przez kandydatów. Tabela 1 przedstawia wyodrębnione dwie grupy badawcze.

Tabela 1. Zakres decyzji o udziale w rekrutacji poniżej i inni niż poniżej swoich kwalifikacji.

\begin{tabular}{|c|c|c|}
\hline Składowe Kwalifikacji & $\begin{array}{c}\text { Zakres decyzji o udziale } \\
\text { w rekrutacji osób in- } \\
\text { nych niż poniżej swo- } \\
\text { ich kwalifikacji }\end{array}$ & $\begin{array}{c}\text { Zakres decyzji o udziale } \\
\text { w rekrutacji osób poni- } \\
\text { zej swoich kwalifikacji }\end{array}$ \\
\hline Wykształcenie & $1-4$ & $5-7$ \\
\hline Staż pracy & $1-2$ & $3-4$ \\
\hline Doświadczenie & $0-3$ & $4-9$ \\
\hline Zakres (suma) & $11-20$ & $2-10$ \\
\hline
\end{tabular}

W tabeli 1 wyodrębniono zakres dwóch grup badawczych decyzji o udziale w rekrutacji. Pierwszy to zakres decyzji o udziale w rekrutacji osób innych niż poniżej kwalifikacji (ta grupa badawcza nie jest przedmiotem badań w tym artykule). Drugi to zakres decyzji o udziale w rekrutacji osób poniżej swoich kwalifikacji. Zsumowany zakres grupy poniżej kwalifikacji zawiera się na skali od 11 do 20, natomiast innych niż poniżej kwalifikacji od 2 do 10.

Zmienna objaśniająca to wartości życiowe (według Schwartza) podejmującego decyzję o pracy. Kwestionariusz Wartości Schwartza PVQ-R2 został oparty na teorii oraz utworzonym modelu wartości Shaloma Schwartza. Zdefiniował on wartość jako przekonania pełniące funkcję kryteriów i zasad, a także standardów służące człowiekowi do selekcjonowania i oceniania działań, a także oceniania zdarzeń, ludzi i samego siebie ${ }^{23}$.Według autora wartości są świadomym i względnie stałym celem. Wartości tworzą kontinuum, które podzielone jest na bardziej szczegółowe lub bardziej ogólne jednostki.. Kontinuum wartości jest według Schwartza ${ }^{24}$ kontinuum motywacyjnym. Oznacza to że wartości usytuowane obok

\footnotetext{
${ }^{23}$ Schwartz, „Aktywizacja osobistych standardów normatywnych”.

${ }^{24}$ Tenże, „An Overview of the Schwartz Theory of Basic Values”. Online Readings in Psychology and Culture 2, nr 1 (2012): 3-20.
} 
siebie są motywacyjnie podobne, w związku z czym mogą być realizowane w jednym działaniu.

Obecnie najnowsza przyjęta i zmodyfikowana wersja Kwestionariusza PVQR2 składa się z 19 wartości. Rzetelność została zweryfikowana wskaźnikiem a Cronbacha. Itemy, które uzyskiwały niską moc dyskryminacyjną i skale o niskim współczynniku, były w kolejnych wersjach modyfikowane. Ostatecznie dla 19 wartości uzyskano satysfakcjonujące wyniki a Cronbacha mieszczące się od 0,61 do 0,83 .

Tabela 2 przedstawia krótką charakterystykę wartości oraz stosowane skróty od nazw angielskich.

Tabela 2. Charakterystyka wartości Kwestionariusza PVQ-R225.

\begin{tabular}{|l|l|l|}
\hline Wartość & Skrót & Charakterystyka \\
\hline $\begin{array}{l}\text { Kierowanie } \\
\text { sobą w myśle- } \\
\text { niu }\end{array}$ & SDT & $\begin{array}{l}\text { Niezależność myślenia, kształtowanie własnego po- } \\
\text { glądu na świat }\end{array}$ \\
\hline $\begin{array}{l}\text { Kierowanie } \\
\text { sobą w działa- } \\
\text { niu }\end{array}$ & SDA & $\begin{array}{l}\text { Niezależność w podejmowaniu decyzji i realizacji } \\
\text { wybranych przez siebie celów; wolność w wyborze } \\
\text { działań }\end{array}$ \\
\hline Stymulacja & ST & Zmienność, nowość, podniecenie \\
\hline Hedonizm & HE & Przyjemność, zmysłowe zaspokojenie \\
\hline Osiągnięcia & AC & $\begin{array}{l}\text { Osobisty sukces osiągnięty zgodnie ze społecznymi } \\
\text { standardami }\end{array}$ \\
\hline $\begin{array}{l}\text { Władza nad } \\
\text { ludźmi }\end{array}$ & POD & $\begin{array}{l}\text { Władza nad ludźmi, sprawowanie kontroli nad ma- } \\
\text { terialnymi i społecznymi zasobami }\end{array}$ \\
\hline $\begin{array}{l}\text { Władza nad } \\
\text { zasobami }\end{array}$ & POR & $\begin{array}{l}\text { Władza nad zasobami, sprawowanie kontroli nad } \\
\text { materialnymi i społecznymi zasobami }\end{array}$ \\
\hline Prestiż & FAC & $\begin{array}{l}\text { Podtrzymywanie i ochrona swojego wizerunku, sta- } \\
\text { tusu społecznego }\end{array}$ \\
\hline
\end{tabular}

${ }^{25}$ Jan Cieniuch, Eldad Davidov, Michele Vecchione, ,The Cross-National Invariance Properties of a New Scale to Measure 19 Basic Human Values: A Test Across Eight Countries", Journal of CrossCultural Psychology 45, nr 5 (2014): 764-776, DOI: 10.1177/0022022114527348 


\begin{tabular}{|l|l|l|}
\hline $\begin{array}{l}\text { Bezpieczeń- } \\
\text { stwo osobiste }\end{array}$ & SEP & $\begin{array}{l}\text { Bezpieczeństwo w najbliższym, bezpośrednim oto- } \\
\text { czeniu }\end{array}$ \\
\hline $\begin{array}{l}\text { Bezpieczeń- } \\
\text { stwo społeczne }\end{array}$ & SES & Bezpieczeństwo i stabilność w społeczeństwie \\
\hline $\begin{array}{l}\text { Przystosowa- } \\
\text { nie do reguł }\end{array}$ & COR & $\begin{array}{l}\text { Podporządkowanie się regułom, prawu jak i formal- } \\
\text { nym wymaganiom osób sprawujących władzę }\end{array}$ \\
\hline $\begin{array}{l}\text { Przystosowa- } \\
\text { nie do ludzi }\end{array}$ & COI & Unikanie krzywdzenia i denerwowania innych ludzi \\
\hline Tradycja & TR & $\begin{array}{l}\text { Akceptacja i podtrzymywanie zwyczajów, idei i tra- } \\
\text { dycji własnej kultury, religii lub rodziny; respekt w } \\
\text { stosunku do tradycji }\end{array}$ \\
\hline Pokora & HU & $\begin{array}{l}\text { Uznanie małej istotności swojego miejsca w świecie } \\
\text { i historii }\end{array}$ \\
\hline $\begin{array}{l}\text { Życzliwość- } \\
\text { niezawodność }\end{array}$ & BED & $\begin{array}{l}\text { Bycie niezawodnym, godnym zaufania członkiem } \\
\text { grupy }\end{array}$ \\
\hline $\begin{array}{l}\text { Życzliwość- } \\
\text { troskliwość }\end{array}$ & BEC & Troska o dobra innych członków grupy \\
\hline $\begin{array}{l}\text { Uniwersalizm } \\
\text { społeczny }\end{array}$ & UNC & $\begin{array}{l}\text { Dążenie do równości, sprawiedliwości i dobra } \\
\text { wszystkich ludzi }\end{array}$ \\
\hline $\begin{array}{l}\text { Uniwersalizm } \\
\text { ekologiczny }\end{array}$ & UNN & $\begin{array}{l}\text { Ochrona środowiska naturalnego jak i ochrona } \\
\text { przyrody }\end{array}$ \\
\hline $\begin{array}{l}\text { Uniwersalizm- } \\
\text { Tolerancja }\end{array}$ & UNT & $\begin{array}{l}\text { Akceptacja i zrozumienie innych osób, różniących } \\
\text { się od danej osoby }\end{array}$ \\
\hline
\end{tabular}

\section{Wyniki}

Tabela 3 przedstawia statystyki opisowe Wartości życiowych Schwartza PVQ- R2 w wartościach centralnych oraz 19 wartościach podstawowych. 
Pobrane z czasopisma http://kulturaiwartosci.journals.umcs.pl

Data: 26/04/2023 14:45:06

Ewelina Okoniewska, Psychologiczne decyzje podejmowania pracy...

Tabela3. Statystyki opisowe zmiennych Wartości życiowych Schwartza PVQ- R2.

\begin{tabular}{|c|c|c|c|c|c|c|}
\hline $\begin{array}{c}\text { Nazwa zmien- } \\
\text { nej }\end{array}$ & Min & Max & $\begin{array}{l}\text { Średnia } \\
\text { (M Licz.) }\end{array}$ & $\begin{array}{c}\text { Odchylenie } \\
\text { Standardowe } \\
\text { (SD \%) }\end{array}$ & Skośność & Kurtoza \\
\hline $\begin{array}{c}\text { Otwartość na } \\
\text { zmianę } \\
\text { (Centr) }\end{array}$ & 2 & 6 & 4,47 & 0,70 & 0,27 & $-0,40$ \\
\hline $\begin{array}{c}\text { Umacnianie } \\
\text { siebie (Centr) }\end{array}$ & 1,56 & 5,59 & 3,50 & 0,80 & 0,29 & $-0,41$ \\
\hline $\begin{array}{l}\text { Zachowaw- } \\
\text { czość (Cent) }\end{array}$ & 2 & 6 & 4,59 & 0,69 & $-0,31$ & 0,30 \\
\hline $\begin{array}{c}\text { Przekraczanie } \\
\text { siebie (Cent) }\end{array}$ & 2,93 & 6 & 4,90 & 0,68 & $-0,62$ & $-0,03$ \\
\hline $\begin{array}{c}\text { Kierowanie } \\
\text { sobą w myśle- } \\
\text { niu (SDT) }\end{array}$ & 2 & 6 & 4,64 & 0,88 & $-0,40$ & $-0,30$ \\
\hline $\begin{array}{c}\text { Kierowanie } \\
\text { sobą w działa- } \\
\text { niu (SDA) }\end{array}$ & 2,67 & 6 & 4,84 & 0,82 & $-0,40$ & $-0,46$ \\
\hline $\begin{array}{l}\text { Stymulacja } \\
\text { (ST) }\end{array}$ & 1 & 6 & 4,07 & 0,99 & $-0,13$ & $-0,36$ \\
\hline $\begin{array}{l}\text { Hedonizm } \\
\text { (HE) }\end{array}$ & 1,33 & 6 & 4,30 & 0,83 & $-0,32$ & 0,37 \\
\hline $\begin{array}{l}\text { Osiągnięcia } \\
\text { (AC) }\end{array}$ & 2 & 6 & 4,79 & 0,84 & $-0,72$ & 0,33 \\
\hline $\begin{array}{c}\text { Władza nad } \\
\text { ludźmi (POD) }\end{array}$ & 1 & 6 & 2,59 & 1,18 & 0,55 & $-0,37$ \\
\hline $\begin{array}{l}\text { Władza nad } \\
\text { zasobami } \\
\text { (POR) }\end{array}$ & 1 & 5,67 & 3,14 & 1,15 & 0,01 & $-0,77$ \\
\hline Prestiż (FAC) & 1,67 & 6 & 4,70 & 0,92 & $-0,93$ & 0,60 \\
\hline
\end{tabular}


Pobrane z czasopisma http://kulturaiwartosci.journals.umcs.pl

Data: 26/04/2023 14:45:06

Ewelina Okoniewska, Psychologiczne decyzje podejmowania pracy...

\begin{tabular}{|c|c|c|c|c|c|c|}
\hline $\begin{array}{l}\text { Bezpieczeń- } \\
\text { stwo osobiste } \\
\quad(\mathrm{SEP})\end{array}$ & 2,33 & 6 & 4,79 & 0,85 & $-0,65$ & $-0,01$ \\
\hline $\begin{array}{c}\text { Bezpieczeń- } \\
\text { stwo spo- } \\
\text { łeczne (SES) }\end{array}$ & 2,33 & 6 & 4,66 & 0,88 & $-0,39$ & $-0,51$ \\
\hline $\begin{array}{l}\text { Przystosowa- } \\
\text { nie do reguł } \\
\quad(\mathrm{COR})\end{array}$ & 1 & 6 & 4,59 & 0,99 & $-0,62$ & 0,22 \\
\hline $\begin{array}{l}\text { Przystosowa- } \\
\text { nie do ludzi } \\
\quad(\mathrm{COI})\end{array}$ & 1 & 6 & 4,39 & 0,99 & $-0,49$ & 0,27 \\
\hline Tradycja (TR) & 1,68 & 6 & 4,70 & 0,85 & $-0,33$ & 0,38 \\
\hline Pokora (HU) & 2 & 6 & 4,28 & 0,98 & $-0,14$ & $-0,35$ \\
\hline $\begin{array}{l}\text { Życzliwość- } \\
\text { niezawodność } \\
(\mathrm{BED})\end{array}$ & 2 & 6 & 5,23 & 0,81 & $-1,26$ & 1,54 \\
\hline $\begin{array}{c}\text { Życzliwość- } \\
\text { troskliwość } \\
(\mathrm{BEC})\end{array}$ & 2 & 6 & 5,10 & 0,80 & $-0,90$ & 0,41 \\
\hline $\begin{array}{l}\text { Uniwersalizm } \\
\text { społeczny } \\
\text { (UNC) }\end{array}$ & 2 & 6 & 4,91 & 0,84 & $-0,72$ & 0,21 \\
\hline $\begin{array}{l}\text { Uniwersalizm } \\
\text { ekologiczny } \\
\text { (UNN) }\end{array}$ & 1,33 & 6 & 4,32 & 1,06 & $-0,35$ & $-0,24$ \\
\hline $\begin{array}{l}\text { Uniwersa- } \\
\text { lizm- toleran- } \\
\text { cja (UNT) }\end{array}$ & 1 & 6 & 4,93 & 0,88 & $-0,99$ & 1,31 \\
\hline
\end{tabular}


Zmienne przedstawione w tabeli 3 charakteryzują się rozpiętością wyników mieszczących się od 1 do 6. Największą uzyskaną średnią odnotowano w wartościach: przekraczanie siebie (cent), życzliwość - niezawodowość, życzliwość - troskliwość. Zmienne posiadają prawostronną asymetrię rozkładu to otwartość na zmianę, umacnianie siebie, władza nad ludźmi, władza nad zasobami. Pozostałe zmienne charakteryzują się ujemnoskośnym rozkładem. Wyniki wykazują leptokurtyczność występują w zachowawczości (cent), hedonizm, osiągnięcia, prestiż, przystosowanie do reguł, przystosowanie do ludzi, życzliwość - niezawodność, życzliwość - troskliwość, uniwersalizm społeczny oraz uniwersalizm - tolerancja, co oznacza mniejsze skoncentrowanie ich wokół średniej, natomiast wyniki w pozostałych wartościach wykazuję słabą leptokurtczność.

Tabela nr 4 prezentuje korelacje między poszczególnymi skalami Wartości Schwartza, a decyzją o udziale w rekrutacji poniżej kwalifikacji w wyniku ogólnym, stażu pracy, doświadczeniu zawodowym i wykształceniu.

Tabela4. Korelacje rho Spearmana między poszczególnymi skalami Wartości Schwartza PVQ a decyzją o udziale w rekrutacji poniżej kwalifikacji w wyniku ogólnym, stażu pracy, doświadczeniu zawodowym i wykształceniu, gdzie ${ }^{\star} \mathrm{p}<0,05,{ }^{*} \mathrm{p}<0,01$, ${ }^{* * *} \mathrm{p}<0,001$.

\begin{tabular}{|c|c|c|c|c|}
\hline $\begin{array}{l}\text { skala } \\
\text { PVQ }\end{array}$ & $\begin{array}{c}\text { Decyzja o } \\
\text { udziale w re- } \\
\text { krutacji poni- } \\
\text { żej kwalifika- } \\
\text { cji (Wynik } \\
\text { ogólny) }\end{array}$ & $\begin{array}{c}\text { Decyzja o } \\
\text { udziale w re- } \\
\text { krutacji poni- } \\
\text { żej kwalifikacji } \\
\text { (Staż pracy) }\end{array}$ & $\begin{array}{c}\text { Decyzja o } \\
\text { udziale w } \\
\text { rekrutacji } \\
\text { poniżej } \\
\text { kwalifikacji } \\
\text { (Doświad- } \\
\text { czenie za- } \\
\text { wodowe) }\end{array}$ & $\begin{array}{c}\text { Decyzja o } \\
\text { udziale w } \\
\text { rekrutacji } \\
\text { poniżej } \\
\text { kwalifikacji } \\
\text { (Wykształ- } \\
\text { cenie) }\end{array}$ \\
\hline $\begin{array}{l}\text { Otwartość na } \\
\text { zmianę } \\
\text { (Centr) }\end{array}$ & $-0,202^{\star}$ & $-0,001$ & $-0,176$ & $-0,021$ \\
\hline $\begin{array}{l}\text { Umacnianie } \\
\text { siebie (Centr) }\end{array}$ & $-0,016$ & 0,037 & $-0,020$ & 0,007 \\
\hline
\end{tabular}


Pobrane z czasopisma http://kulturaiwartosci.journals.umcs.pl

\begin{tabular}{|c|c|c|c|c|}
\hline $\begin{array}{l}\text { Zachowaw- } \\
\text { czość (Cent) }\end{array}$ & $-0,112$ & 0,136 & $-0,096$ & $-0,046$ \\
\hline \begin{tabular}{ll}
\multicolumn{2}{l}{ Przekracza- } \\
nie siebie \\
$($ Cent $)$
\end{tabular} & $0,105^{\star}$ & 0,107 & $-0,012$ & 0,000 \\
\hline $\begin{array}{l}\text { Kierowanie } \\
\text { sobą w my- } \\
\text { śleniu (SDT) }\end{array}$ & $-0,186^{*}$ & $-0,068$ & $-0,230^{*}$ & 0,014 \\
\hline $\begin{array}{l}\text { Kierowanie } \\
\text { sobą w dzia- } \\
\text { łaniu (SDA) }\end{array}$ & $-0,133$ & 0,063 & $-0,090$ & $-0,030$ \\
\hline $\begin{array}{l}\text { Stymulacja } \\
(\mathrm{ST})\end{array}$ & $-0,133$ & 0,90 & $-0,046$ & 0,024 \\
\hline $\begin{array}{l}\text { Hedonizm } \\
(\mathrm{HE})\end{array}$ & $-0,197^{\star}$ & $-0,100$ & $-0,199$ & $-0,086$ \\
\hline $\begin{array}{l}\text { Osiągnięcia } \\
\text { (AC) }\end{array}$ & $-0,092$ & $-0,112$ & $-0,061$ & 0,008 \\
\hline $\begin{array}{l}\text { Władza nad } \\
\text { ludźmi } \\
(\text { POD) }\end{array}$ & 0,007 & 0,081 & $-0,079$ & 0,038 \\
\hline $\begin{array}{l}\text { Władza nad } \\
\text { zasobami } \\
(\text { POR })\end{array}$ & 0,022 & 0,080 & 0,076 & $-0,027$ \\
\hline $\begin{array}{l}\text { Prestiż } \\
(\mathrm{FAC}) \mathrm{POF}\end{array}$ & $-0,224^{\star *}$ & 0,068 & $-0,056$ & 0,031 \\
\hline $\begin{array}{l}\text { Bezpieczeń- } \\
\text { stwo osobiste } \\
(\mathrm{SEP})\end{array}$ & $-0,132$ & 0,086 & $-0,065$ & $-0,096$ \\
\hline $\begin{array}{l}\text { Bezpieczeń- } \\
\text { stwo spo- } \\
\text { łeczne (SES) }\end{array}$ & $-0,012$ & 0,036 & $-0,113$ & $-0,088$ \\
\hline $\begin{array}{l}\text { Przystosowa- } \\
\text { nie do reguł } \\
(\mathrm{COR})\end{array}$ & $-0,032$ & 0,092 & 0,022 & $-0,136$ \\
\hline
\end{tabular}




\begin{tabular}{|l|c|c|c|c|}
\hline $\begin{array}{l}\text { Przystosowa- } \\
\text { nie do ludzi } \\
\text { (COI) }\end{array}$ & $-0,159$ & $0,167^{*}$ & $-0,043$ & 0,105 \\
\hline $\begin{array}{l}\text { Tradycja } \\
\text { (TR) }\end{array}$ & $-0,130$ & $0,151^{*}$ & $-0,146$ & $-0,097$ \\
\hline Pokora (HU) & $-0,031$ & 0,075 & $-0,078$ & 0,079 \\
\hline $\begin{array}{l}\text { Życzliwość- } \\
\text { niezawod- } \\
\text { ność (BED) }\end{array}$ & $-0,161$ & 0,009 & $-0,025$ & $-0,070$ \\
\hline $\begin{array}{l}\text { Życzliwość- } \\
\text { troskliwość } \\
\text { (BEC) }\end{array}$ & $-0,214^{*}$ & $-0,004$ & $-0,009$ & $-0,085$ \\
\hline $\begin{array}{l}\text { Uniwersa- } \\
\text { lizm spo- } \\
\text { leczny } \\
\text { (UNC) }\end{array}$ & $-0,034$ & 0,093 & 0,037 & 0,037 \\
\hline $\begin{array}{l}\text { Uniwersa- } \\
\text { lizm ekolo- } \\
\text { giczny } \\
\text { (UNN) }\end{array}$ & 0,001 & $0,151^{*}$ & $-0,061$ & 0,073 \\
\hline $\begin{array}{l}\text { Uniwersa- } \\
\text { lizm- tole- } \\
\text { rancja (UNT) }\end{array}$ & $-0,029$ & $0,149^{*}$ & 0,016 & 0,021 \\
\hline
\end{tabular}

W grupie osób podejmujących decyzję o udziale w rekrutacji poniżej swoich kwalifikacji zaobserwowano prawidłowość zgodnie, z którą im niższa jest otwartość na zmianę, kierowanie sobą w myśleniu, hedonizm, prestiż, życzliwość - troskliwość, tym wyższy jest poziom podejmowania decyzji o rekrutacji poniżej kwalifikacji w wyniku ogólnym. W kolejnej składowej tej zmiennej zaobserwowano proporcjonalność, która mówi o tym, że im wyższe jest przekraczanie siebie, przystosowanie do ludzi, tradycja, uniwersalizm ekologiczny, uniwersalizm - tolerancja, tym wyższy jest poziom podejmowania decyzji o rekrutacji poniżej kwalifikacji pod względem stażu pracy; zaobserwowano też, że im niższe jest kierowanie 
sobą w myśleniu, tym wyższy jest poziom podejmowania decyzji o rekrutacji poniżej kwalifikacji pod względem doświadczenia zawodowego. W grupie badawczej w składowej wykształcenie nie zaobserwowano zależności. Nie stwierdzono również zależności pomiędzy pozostałymi zmiennymi Wartościami Schwartza, takimi jak umacnianie siebie (wartość centralna), zachowawczość (wartość centralna), kierowanie sobą w działaniu, stymulacja, osiągnięcia, władza nad ludźmi, władza nad zasobami, bezpieczeństwo osobiste, bezpieczeństwo społeczne, przystosowanie do reguł, pokora, życzliwość - niezawodność, uniwersalizm społeczny.

\section{Analiza wyników i wnioski}

Analizując wyniki badań oraz grupę badawczą, można stwierdzić, że decydenci z tej grupy posiadają większy wynik w wartościach centralnych: zachowawczości i przekraczanie siebie, co wskazuje na podejście nieco bardziej konserwatywne, zgodne z kulturą, a także normami osobistymi i społecznymi. Osoby te uzyskały różnice we wszystkich pozostałych wartościach wchodzących do kołowego modelu wartości centralnej: zachowawczości i przekraczania siebie. Otrzymały wyższe wyniki w bezpieczeństwie społecznym, ceniąc sobie stabilność w społeczeństwie oraz w bezpieczeństwie osobistym, związanym ze stabilnością w bezpośrednim otoczeniu, rodzinie. Można wnioskować, że kandydaci aplikujący poniżej swoich kwalifikacji podejmują decyzję kierując się dobrem najbliższych, stabilnością; ważne jest dla nich bezpieczeństwo i zaufanie w rodzinie. Zgodnie z koncepcją Popielskiego, „zaufanie pokładane w drugiej osobie zakłada, że człowieka należy ujmować jako podmiot otwarty, realizujący się poprzez spełnianie wartości. [...] Człowiek jako osoba odpowiedzialna zaspokaja podmiotowe i społeczne dążenia, cele i wartości. To wszystko zaś otwiera przed osobą ludzką wprost nieograniczone możliwości rozwojowe"26.

Osoby badane uzyskały również wyższy wynik w przystosowaniu do reguł, przystosowaniu do ludzi i w tradycji. Wartości te są umiejscowione na kontinuum Wartości Schwartza w wartości centralnej: zachowawczość; wysoki wynik świadczy o możliwości ograniczenia własnych działań, dążeń, które mogłoby krzywdzić

\footnotetext{
${ }^{26}$ Kazimierz Popielski, „Logoteoria i logoterapia w kontekście psychologii współczesnej”, w: Człowiek - pytanie otwarte. Studia z logoterapii i logoterapii, red. Kazimierz Popielski (Lublin: Wydawnictwo KUL, 1987), 50.
} 
innych lub naruszać normy społeczne i oczekiwania. Osoby te, w imię tradycji i dobra innych, wolą podporządkować się regułom, które mogą być również ustalane na etapie rekrutacji, takim jak przyporządkowanie do danego stanowiska pracy. Kolejne analizy wskazały, że w grupie osób podejmujących decyzję o rekrutacji poniżej kwalifikacji wraz ze wzrostem przystosowania do ludzi, tradycją, uniwersalizmem ekologicznym oraz uniwersalizmem - tolerancją w stażu pracy pojawia się wzrost podejmowania decyzji o aplikacji poniżej swoich kwalifikacji. Warto zwrócić uwagę w interpretacji na istotność w grupie staż pracy. Prawdopodobnie, poprzez swój staż pracy badani kształtują osobisty system wartości, który w tym wypadku opiera się na tradycyjnych wartościach, unikaniu krzywdzenia innych ludzi i środowiska naturalnego, a także na tolerancyjnym podejściu do świata.

Docelowa grupa badawcza otrzymała wyższe wyniki w wartości centralnej Przekraczanie siebie, gdzie wysoki wynik sugeruje na zrozumienie, szacunek i tolerancję w stosunku do innych ludzi i przyrody. Wysoki wynik z grupy tej wartości został odnotowany w uniwersalizmie ekologicznym, oznaczającym wysoką troskę o środowisko naturalne, co z dużym prawdopodobieństwem łączy się z przystosowaniem do reguł związanych z poszanowaniem środowiska przyrodniczego. Badania wskazują na dużą wartość szacunku i wzajemnego zrozumienia wśród ludzi ${ }^{27}$.

Dalsze analizy wskazały, że w grupie osób podejmujących decyzję o rekrutacji poniżej kwalifikacji wraz ze spadkiem otwartości na zmianę, hedonizmem, prestiżem, życzliwością - troskliwością w wyniku ogólnym oraz kierowaniu sobą w myśleniu, w wyniku ogólnym i w doświadczeniu towarzyszy spadek podejmowania decyzji o aplikacji poniżej swoich kwalifikacji. Interpretacja wskazuje na uzyskanie profilu osoby o małym stopniu niezależności w myśleniu, podporządkowaniu się innym (także osobom ze środowiska pracy) w kształtowaniu poglądu na świat i możliwości rozwijania swoich umiejętności zawodowych. Osoby badane podejmują swoją decyzję o podjęciu pracy poniżej kwalifikacji kosztem przyjemności z wykonywania pracy czy prestiżu i wizerunku publicznego. Wartość życzliwość - troskliwość odnosi się do troski o członków grupy zawodowej, która $\mathrm{w}$ tym przypadku nie jest rozpatrywana w kategoriach bliskich czy rodziny. Badania wskazują na to, że motywy osób będących w sytuacji zmiany pracy, związane

${ }^{27}$ Clive Seligman, Albert Katz, The Dynamics of Value Systems (New Jersey: Lawrence Erlbaum Ass. Publishers, 1996). 
są z czynnikami współpracy, połączeniem zadań zawodowych z życiem rodzinnym oraz swobody w wykonywania zadań ${ }^{28}$.

Zgodność wartości ma duże znaczenie w podejmowaniu życiowych decyzji, wpływa na satysfakcję i zaangażowanie w pracę ${ }^{29}$. Badania związane z kulturą organizacyjną i systemem wartości pokazują, że spójny przekaz tych idei wpływa na motywację pracowników ${ }^{30}$. Wartości odnoszą się do realizowania potrzeb wyższego i niższego rzędu, podejmowane zachowania są przez nie zdeterminowane. Jednostka może mieć nasiloną potrzebę bezpieczeństwa najbliższych oraz dużą potrzebę stabilności z racji wychowania, tradycji lub światopoglądu ${ }^{31}$. System wartości warunkuje ludzkie działania, jest motywatorem do podejmowania decyzji, które mogą być oceniane jako dyskusyjne lub wątpliwe ${ }^{32}$.

\section{Bibliografia}

Adair, John. Podejmowanie decyzji. Warszawa: Studio emKa, 1998.

Bäck, Emma, Peter Esaiasson, Mikael Gilljam, Ola Svenson, Torun Lindholm. „Post decision consolidation in large group decision making”. Scandinavian Journal of Psychology 52, nr 4 (2011): 320-328.

Biela, Adam. Informacja a decyzja. Warszawa: PWN, 1976.

Boxx, Randly, Randall Odom i Mark Dunn. „Organizational Values and Value Congruency and Their Impact on Satisfaction, Commitment, and Cohesion: An Empirical Examination within the Public Sector". Public Personnel Management 20, nr 2 (1991): 195-205. DOI: $10.1177 / 009102609102000207$.

Cieciuch, Jan. „Pomiar wartości w zmodyfikowanym modelu Shaloma Schwartza”. Psychologia Społeczna 8, nr 1 (2013): 22-41.

Cieniuch, Jan, Eldad Davidov i Michele Vecchione. „The Cross-National Invariance Properties of a New Scale to Measure 19 Basic Human Values: A Test Across Eight Countries".

\footnotetext{
${ }^{28}$ Francois Fraccaroli, „Stabilité et changement des significations du travail. Une recherche longitudinale sur la transition école-emploi”, Le Travail Humain 57, nr 2 (1994): 45-162.

${ }^{29}$ Randly Boxx, Randall Odom, Mark Dunn, „Organizational Values and Value Congruency and Their Impact on Satisfaction, Commitment, and Cohesion: An Empirical Examination within the Public Sector", Public Personnel Management 20, nr 2 (1991): 195-205, DOI: 10.1177/009102609102000207.

${ }^{30} \mathrm{Enz}$, „The role of value”.

${ }^{31}$ Schwarttz, „Aktywizacja osobistych standardów normatywnych”.

${ }^{32}$ Jan Reykowski, Motywacja, postawy prospołeczne a osobowość (Warszawa: PWN, 1979).
} 
Pobrane z czasopisma http://kulturaiwartosci.journals.umcs.pl

Ewelina Okoniewska, Psychologiczne decyzje podejmowania pracy...

Journal of Cross-Cultural Psychology 45, nr 5 (2014): 764-776. DOI: $10.1177 / 0022022114527348$

Enz, Cathy. „The role of value congruity in intraorganizational Power”. Administrative Science Quarterly33, nr 2 (1988): 284-304. DOI: 10.2307/2393060.

Falkowski, Andrzej i Tadeusz Tyszka. Psychologia zachowań konsumenckich. Gdańsk: Gdańskie Wydawnictwo Psychologiczne, 2001.

Flynn, Robert. „Effect of unemployment on depressive affect”. W: Depression and the social environment: Research and intervention with neglected populations, red. Philippe Cappeliez, Robert J. Flynn, 185-217. Montreal: McGill-Queen's University Press, 1993.

Fraccaroli, Francois. „Stabilité et changement des significations du travail. Une recherche longitudinale sur la transition école-emploi”. Le Travail Humain 57, nr 2 (1994): 145-162.

Fryzeł, Barbara. Kultura a konkurencyjność przedsiębiorstwa. Toruń: TNOiK Dom Organizatora, 2004.

Gollwitzer, Peter. „Implementation intentions: Strong effects of simple plans”. American Psychologist 54, nr 7 (1999): 493-503. DOI: 10.1037/0003-066X.54.7.493

Hartmann, Nicolai. „O idealnej samoświadomości wartości. Stosunek wartości i powinności. Aktualny stan zagadnienia wartości”. W: Z fenomenologii wartości, red. Włodzimierz Galewicz. Kraków: Wydawnictwo PAT, 1988.

Kabaj, Mieczysław. Badanie bezrobocia długotrwałego. Warszawa: IPiSS, 2001.

Kasl, Stanislav, Eunice Rodriguez, Kathryn Lasch. „The impact of unemployment on health and well-being”. Adversity, Stress, and Psychopathology, red. Bruce Dohrenwend, 111-131. New York: Oxford University Press, 1998.

Kozielecki, Józef. Psychologiczna teoria decyzji. Warszawa: PWN, 1975.

Krąpiec, Mieczysław. „Decyzja - bytem moralnym”. Roczniki Filozoficzne 31, nr 2 (1983): 4765.

Krąpiec, Mieczysław. Ludzka wolność i jej granice. Lublin: Polskie Towarzystwo Tomasza z Akwinu, 2004.

Newell, Allen, Herbert Simon. Human problem solving. Englewood Cliffs: Prentice Hall, 1972.

Oleś, Piotr. Wartościowanie a osobowość. Psychologiczne badanie empiryczne. Lublin: Wydawnictwo KUL, 1989.

Popielski, Kazimierz. „Logoteoria i logoterapia w kontekście psychologii współczesnej”. W: Człowiek - pytanie otwarte. Studia z logoterapii i logoterapii, red. Kazimierz Popielski, 27-65. Lublin: Wydawnictwo Katolickiego Uniwersytetu Lubelskiego, 1987.

Reich, Robert. Praca Narodów. Przygotowanie się do kapitalizmu XXI wieku. Tłum. Lidia Zyblikiewicz. Toruń: Wydawnictwo Adam Marszałek, 1996.

Reykowski, Jan. Motywacja, postawy prospołeczne a osobowość. Warszawa: PWN, 1979.

Scheler, Max. Cierpienie, śmierć i dalsze życie. Tłum. Adam Węgrzecki. Warszawa: PWN, 1994.

Schwartz, Shalom. „Aktywizacja osobistych standardów normatywnych a zachowanie prospołeczne”. Studia Psychologiczne 15 (1976): 5-33.

Schwartz, Shalom. „An Overview of the Schwartz Theory of Basic Values”. Online Readings in Psychology and Culture 2, nr 1 (2012): 3-20. 
Schwartz, Shalom. „Basic human values: theory measurement and applications”. Revue francaise de sociologie 47, nr 4 (2006): 929-968. DOI: 10.1037/0003-066X.54.7.493

Schwartz, Shalom. „Robustness and fruitfulness of a theory of universals in individual human values". Valores e trabalho (2005): 56-95.

Seligman Clive, Albert Katz. The Dynamics of Value Systems. New Jersey: Lawrence Erlbaum Ass. Publishers, 1996.

Stachowicz-Stanusch, Agata. Zarządzanie poprzez wartości. Perspektywa rozwoju współczesnego przedsiębiorstwa. Gliwice: Wydawnictwo Politechniki Śląskiej, 2007.

Svenson, Ola. „Differentiation and consolidation theory of human decision making: A frame of reference for the study of pre- and postdecision process". Acta Psychologica 80, nr 1-3 (1992): 143-168. DOI: 10.1016/0001-6918(92)90044-E.

Terelak, Jan. Psychologia pracy i bezrobocia. Warszawa: Wydawnictwa Akademii Teologii Katolickiej, 1993.

Thurow, Lester. Przyszłość kapitalizmu. Jak dzisiejsze siły ekonomiczne kształtują świat jutra. Tłum. Lech Czyżewski. Wrocław: Wydawnictwo Dolnośląskie, 1999.

Tomkiewicz Anna, Ewa Popławska. „Postawy wartościujące studentów polskich i amerykańskich”. Roczniki Nauk Społecznych XXV, z. 2 (1997): 45-66.

Tyszka, Tadeusz. Decyzje. Perspektywa psychologiczna ekonomiczna. Warszawa: Wydawnictwo Naukowe Scholar, 2010.

\section{Summary}

Psychological decisions to take up jobs below one's skills in the context of values

The study was designed to find out what values are determining people's decisions to enter a recruitment process for jobs which they are unqualified for and which are below their skills level. 302 candidates in groups of job seekers aged 18 to 45 years were surveyed in eleven cities throughout Poland. They filled out a questionnaire stating their personal particulars and giving a description of their work experience acquired in their previous three jobs. Schwartz's Portrait Value Questionnaire PVQ-R2 was also used for the research purpose. The study results offer solid reference material for those involved in job recruitment and human resources policies.

Key words: values, decisions, work below skill level, Schwartz's Portrait Value Questionnaire PVQ-R2 


\section{Zusammenfassung}

\section{Psychologische Entscheidungen bei der Aufnahme von Arbeit unter seinen Qualifikationen im Kontext der Werte}

Das Ziel der durchgeführten Forschungsstudie war die Antwort auf die Frage, welche Werte die Situation der Personen beeinflussen, die sich für die Rekrutierung auf eine niedrig qualifizierte Arbeitsstelle unter ihren Qualifikationen entschieden haben. Im Zusammenhang damit wurden 302 Bewerber in elf Städten in Polen (Lublin, Warszawa, Rzeszow, Lipsko, Poznań, Sandomierz, Gorzyce, Opole, Łódź, Krosno) im Alter von 18 bis 45 Jahren befragt. Die Befragten nahmen an einem Rekrutierungsprozess teil. Sie füllten dabei einen Fragebogen aus, der im ersten Teil demographische Fragen und die Berufserfahrung von den letzten drei Arbeitsstellen enthielt. Im weiteren Teil befand sich Schwartz Value Survey PVQ-R2. Der Artikel ist eine hilfreiche Wissensquelle über die Beschreibung des Profils eines Bewerbers, der sich für eine Arbeitsstelle unter seinen Qualifikationen bewirbt, unter dem Gesichtspunkt seiner Werte. Die Studie kann für Personen hilfreich sein, die für Rekrutierung und Selektion des Personals oder für Personalmanagement zuständig sind.

Schlüsselworte: Werte, Entscheidungen, Arbeit unter seinen Qualifikationen, SchwartzWerte

Information about Author:

EWELINA OKONIEWSKA, PhD, University of Jan Kochanowski in Kielce; address for correspondence: 11 Krakowska St., PL 25-029 Kielce; e-mail: ewelina.okoniewska@ujk.edu.pl 